\title{
PENSION INVESTMENT FUNDS ANALYSIS: A VARIANCE-COMPARISON TESTS OF NON-CONTRIBUTORY (PRE) AND CONTRIBUTORY (POST) SCHEMES IN NIGERIA
}

\author{
Edesiri G. Okoro \\ Nnamdi Azikiwe University, Awka \\ \& \\ Emma I. Okoye \\ Nnamdi Azikiwe University, Awka
}

\begin{abstract}
In Nigeria, pension was established in 2004 through the Pension Reform Act, 2004 and since then, pension schemes have manifested in twofold: 'old' and 'new'. The Pension Act No. 102 of 1979 is the "old pension" (non-contributory) and Pension Reform Act of 2004 (including the restructured/modified Pension Act, 2014) is the "new pension" (contributory) scheme. In this paper, we comparatively evaluated both the non-contributory (pre) and contributory (post) pension schemes in Nigeria. In order to do this, secondary data of pension investment funds was obtained during the period 1994-2014. Based on the analysis of data, we found that the contributory (post) scheme is healthy, reliable and poised towards helping retirees survive as soon as they retire from service. Thus, the contributory (post) scheme significantly improved as a result of the reform in Nigeria, especially in the area of pension investment funds. On the basis of the findings, it was recommended among others that there should be an unrestricted retirement savings scheme and non-remittance of pension contributions by employers to PENCOM. Also, a better return on investment and service delivery from pension fund administrators should be enhanced so as to enhance pension investments and voluntary contributions. Besides this, the internal procedures should be improved upon so that contributions and returns on pension investments due to retirees can be efficiently and swiftly made from pension fund administrators to pensioners on retirement.
\end{abstract}

Keywords: Pension Reform; Contributory Pension Scheme; Non-Contributory Pension Scheme; Defined Benefits; Old and New Pension Schemes

\section{Introduction}

Pension seems not to be the most tenacious issue for Africa; however, it is often debated in the orbit of government, employers of labour, employees as well as the general public. Quite a large number of Sub-Saharan Africa countries do not have meaningful publicly managed pension and social security schemes, though some form of pension schemes are available in a limited number of countries including Nigeria. Stewart and Yermo (2009) provided that universal pension schemes are operated in some Sub-Saharan African countries such as Botswana, Namibia, South Africa, Kenya and Nigeria but with a limited funding. Edogbanya (2013) sees pension as a given sum of money paid on a regular basis to an employee who no longer work for a given organization as a result of old age, disability, retirement or to his/her widowed or dependent children by the state, former employers or from provident fund to which he/she and his/her employer both contributed. Pension scheme in Nigeria was first initiated by the Colonial Administration in the wake of the 1951 Pension Ordinance with retrospective effect from the period 1946 (Nwanne, 2015). Nevertheless, Ahmad (2006) believed that the 1951 Pension Ordinance offered public servants with both pension and gratuity. 
In Nigeria, pension schemes have manifested in twofold: old and new pension schemes. The Pension Act No. 102 of 1979 is referred to as the "old pension scheme" while the Pension Reform Act of 2004 (including the restructured/modified Pension Act, 2014) as the "new pension scheme". The old pension scheme was a non-contributory defined benefit scheme, implying that the employees only was paying into the fund and benefits to be paid to any retiring employee who was entitled to pension/gratuity were predetermined in percentages of final salary on date of retirement and number of years of service with the employer. Contrarily, the new pension scheme is a contributory defined scheme where the amount of benefit accruing to the employee at retirement or cessation of employment solely depends on the total amount of contribution in his/her retirement savings account as at the date of cessation of employment and interest accumulated thereon.

Odia and Okoye (2012) described the new pension scheme as Pay-As-You-Go (PAYG). In order to further improve pension in Nigeria, the Nigerian Stock Exchange (NSE) on January 2, 2013 introduced NSE Pension Index which was made available to the investing public on Thursday July 2, 2015. The purpose of the pension index was geared towards developing other products such as Exchange Traded Products (ETP's), Index Futures and a mechanism for tracking Pension Fund Administrators (PFAs), Custodians of Pension Fund Administrators (CPFA) and others that are deemed to adopt the PENCOM guidelines in Nigeria. Aside this, the NSE pension index served as a benchmark for gauging performance and reporting same to Retirement Savings Accounts (RSA) holders in the country (Proshare Ecosystem, 2016). As of 31 December, 2016, there are forty (40) firms of market capitalization and liquidity in the NSE pension index. In this paper, we analysed pension investment funds of non-contributory (pre) and contributory (post) schemes in Nigeria via a variance-comparison test. The lingering part of this paper encompassed extant literature on pension schemes, theoretical underpinning, results and discussion, conclusion and recommendations.

\section{Literature Review}

Quite a few number of studies have examined pension reform schemes and economic growth in Nigeria, especially after the pension reform Act of 2004 (Nwanne, 2015; Ezugwu \& Itodo, 2014) while there are other studies that evaluated pension reform schemes on employees' productivity and organizational efficiency (Ahmed, Abayomi \& Nureni, 2016; Osondu, 2016; Anazodo, Ezenwile, Chidolue \& Umetiti, 2014; Akalonu \& Ipinyomi, 2014; Essien \& Akuma, 2014; Ahmed \& Oyadiran, 2013; Ayegba, 2013; Odia \& Okoye, 2012) and strength and weaknesses of the pension reform schemes in Nigeria (Odo, Igbeka \& Ani, 2011). Also, there are scanty studies after 2014 owing to the restructured/modified pension scheme, which for instance took into account, a review of the contributory plans for employers (8\%) and employees (10\%), which is at variance with the 2004 pension scheme. For instance, Ahmed, Abayomi \& Nureni (2016) explored the effects of contributory pension scheme on employee's productivity in Lagos State using one hundred and twenty (120) sampled respondents. The data obtained was analysed via regression statistical tool. The analysis revealed that adequate retirement package for retirees significantly influence their productivity as well as positively contributing to organizational efficiency. The implication of their findings if that the contributory pension scheme significantly and positively influence productivity in Nigeria.

A study by Osondu (2016) appraised the implementation of the pension reform act 2004 so as to see whether or not the scheme influences the payment of retirement benefits to the retired employees of the selected federal tertiary institutions as well as if the new pension scheme has helped solved the problem of pension administration in Nigeria. Primary data were 
administered to four randomly selected federal tertiary institutions in the south-east states namely, University of Nigeria, Nsukka, Enugu State, Federal University of Technology, Owerri Imo State; National Root Crops Research Institute Umudike Abia; State and Federal Polytechnic Nekede Owerri Imo State. The research subjects comprised of only retirees under the new pension scheme, effective 2007 and qualitative analysis was conducted based on the data obtained from the field survey. The findings of the study indicated that the application of the provisions of the Pension Act has a positive impact on the employees' retirement benefits or pension and gratuity in the selected institutions.

Nwanne (2015) investigated the contributory pension scheme on economic growth in Nigeria during 2004-2012 using the ordinary least square estimation technique. The study employed two pension parameters: pension funds invested in specified investment outlets and pension savings contributed by private and public sectors in Nigeria on economic growth variable: gross domestic product. The findings showed that pension funds have negatively and significantly influenced economic growth while pension savings positively and significantly impacted on economic growth in Nigeria. Ezugwu and Itodo (2014) analysed the portfolio of pension fund investments by pension funds administrators in Nigeria using secondary data obtained from PENCOM during 2007-2012. Ordinary least square estimation technique was used in analysing the data and findings indicated that equity recorded the highest percent in portfolio of pension fund investments.

Anazodo, Ezenwile, Chidolue and Umetiti (2014) evaluated the effect of the new pension scheme on retirees in Nigeria by utilizing both qualitative and exploratory analysis and found that most retirees are not aware of the operations of the pension fund managers in operation in Nigeria; thus, they have not been able to fully grasp the new pension scheme and this has not improved the welfare of retires. Akalonu and Ipinyomi (2014) comparatively analysed the benefits of the Nigerian Pension Reform Act No. 102 of 1979 and 2004 Pension Reform Act using employees with ages spread between 20 and 60 from different organizations and years of service. In the analysis of data, the t-test was used in analysing the differences in the benefits between the old and new pension reform act. The results indicated that the ratio of gratuity paid by the old scheme and that of the new scheme is a minimum of about 3:5:1 while the pension benefits stand at the minimum ratio of $2: 3: 1$. Thus, they believed that the old pension scheme is better in terms of benefits payable to retirees.

Essien and Akuma (2014) study descriptively compared the new pension scheme with the old pension schemes based on principles (core values) with a view to underlining some areas of departure in both schemes. Their observations on both schemes revealed that the old pension scheme was overwhelmed with financial misappropriation; thus, the old pension scheme was ineffective. Ahmed and Oyadiran (2013) analysed the impact of 2004 pension policy on the welfare of Nigerian civil servants in some selected federal ministries. The data for their study was obtained via questionnaire using random sampling modus operandi. Their findings revealed that the implementation of the contributory pension scheme had significantly improved the welfare of civil servants. Furthermore, findings from their study divulged that the contributory pension scheme has not addressed the problem of sharp practices and inadequate budgetary allocation and as such, the contributory pension scheme is not effective in surmounting the problems experienced by retirees in Nigeria.

Ayegba (2013) evaluated pension administration in Nigeria and the extent to which employers of labour comply in funding the retirement savings account (RSA) of their employees. The 
study employed secondary data as its source of data collection and analysis was performed using non-parametric tests (chi-square). The results suggested that the RSA is not continuously funded by employers of labour under the contributory pension scheme; thus, organizations are not complying with the new pension scheme in Nigeria. A study by Odia and Okoye (2012), descriptively compared the old pension scheme and new pension scheme in Nigeria and found that the new pension scheme brought into limelight a defined contributory scheme unlike the old scheme which was largely defined benefits.

Odo, Igbeka and Ani (2011) provided a theoretical analysis of the public-sector pension reform in Nigeria by ascertaining the roots of the crisis which made reform inevitable. They also evaluated the strength, weakness and measures aimed at remedying the weaknesses inherent the pension reform in Nigeria. They observed that employers and employees were forced by law to provide money anticipated to pay pension claims at retirement, thus making a departure from the past where no such provisions were made, rather payment of pension was contingent on budgetary allocations which were hardly insufficient. In the stream of studies inter-alia, there is little or no empirical studies on a pre-and post-pension scheme analysis in Nigeria so as to see whether there is variation in both schemes. Thus, our study is one of the first in Nigeria that provides a scientific inquiry into this area by comparatively analysing both the contributory and non-contributory schemes using a variance-comparison tests.

\section{Theoretical Underpinning}

The theoretical framework of this paper is premised on the 'Ecological Theory of Administrative Weaknesses'(ETAW) postulated by Professor F.W. Riggs. The underlying philosophy of ETAW is that administrative weaknesses lead to poor performance of the public organizations caused by the interpretation of newness and conformity (Anazodo et.al, 2014). Fundamentally, the theory (ETAW) sees administrative institutions as weak as a result of environmental constraints affecting them. The idea is that these constraints occasioned by the environment, thwart administrative institutions in achieving performance in public organizations. This has been the case of pension schemes in Nigeria due to the weaknesses inherent in the administrative capacities of government in ensuring that the scheme achieves what it is intended to. Relating this theory to the present study, it thus implies that due to the administrative weaknesses inherent in the old pension scheme, caused by inadequate funding, outright fraud irregularities, diversion of funds among others, gave rise to the new pension scheme. The purpose of which was to strengthen the administrative processes of the new pension scheme in the country.

\section{Methods}

This paper comparatively analysed the variation in the old pension scheme and that of the new pension scheme in Nigeria so as to see whether there is a variation in both schemes as well as whether it has either improved or not. Owing to the fact that the aim is directed at ascertaining the variants or differences in both schemes (contributory and non-contributory), a variancecomparison tests (VCT) was performed. According to Markowski \& Markowski (1990), VCT measures the differences between one or more sample group/variables. However, we conducted a two-sample VCT using variables. In order to do a comparative analysis using VCT, secondary data was obtained. Data of Pension Investment Funds (PIF) in Nigeria were obtained from the Pension Commission (PENCOM) Annual Reports during the period 19942016. The study captured the period before and after the 2004 pension scheme. Thus, we looked at 10years (1994-2003) before the 2004 pension scheme and 10years (2005-2014) after the 2004 pension scheme. However, year 2004 was regarded as the base year because pension 
reform occurred in that year and as such, it was excluded in our study. Furthermore, the signs and size of t-statistics were employed to test the statistical significance of the variables as well as to determine the variant in both schemes (contributory and non-contributory) operated by Nigeria in the past and in recent times. The analysis was conducted using the statistical windows software - STATA 13.0 version.

\section{Results and Discussion}

This section dealt with the presentation of the variance comparison tests (VCT) as well as the discussion of results. Table 1 above reports the result of the variance-ratio test for pension investment funds during the pre (contributory) and post (non-contributory) pension era in Nigeria. From the table above, it can be seen that the mean, standard error and standard deviation of the variable produced a remarkable $95 \%$ confidence internal.

Table 1: Variance-Ratio Test for Pension Investment Funds during Pre and Post Pension Era

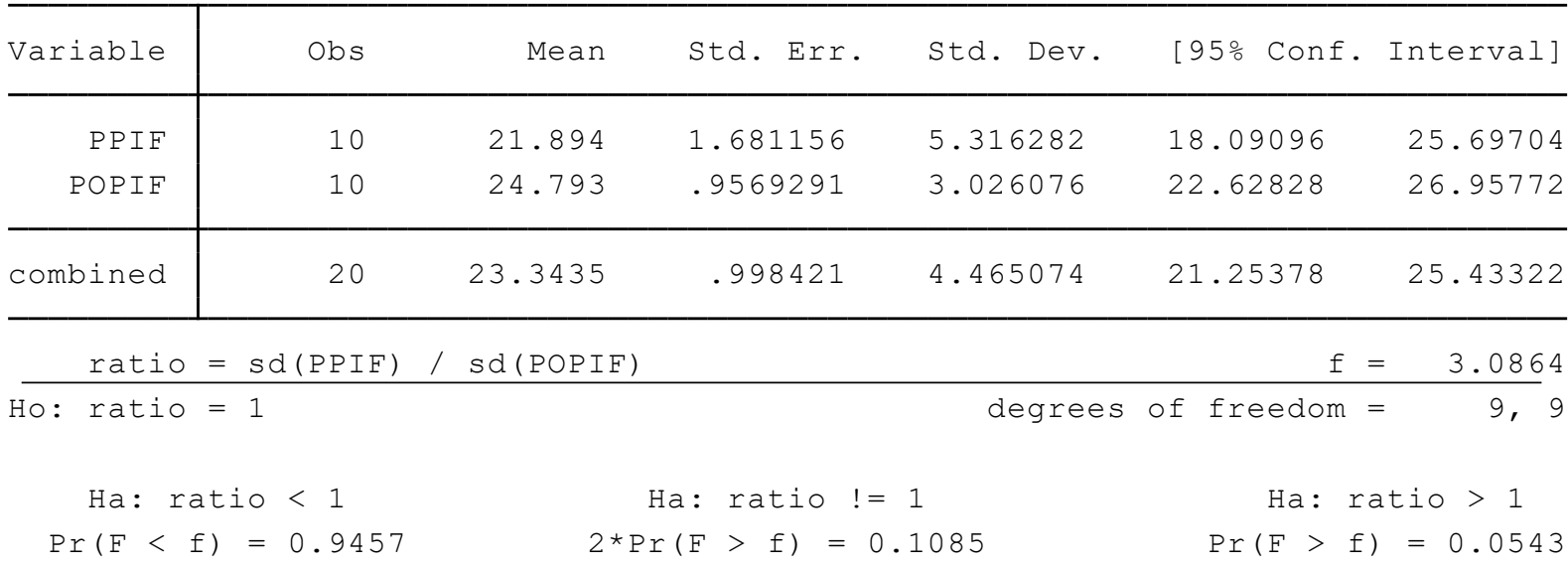

The $95 \%$ confidence interval of the mean, standard error and standard deviation during the prepension era (PPIF) is $18.09 \%$ and $25.70 \%$ while the post-pension era (POPIF) is $22.62 \%$ and $26.96 \%$. Furthermore, the calculated variance-ratio is $\mathrm{f}_{\text {-cal }}=3.0864$ and the tabulated is $\mathrm{f}_{\text {-tab}}=3.18$. More specifically, the p-value which is the probability of the observed test statistic showed $\mathrm{P}(\mathrm{R}<3.0864)=\mathrm{F}(9,9,3.0864)=0.9457$ in relation to one-tailed test while for the two-tailed test is $\mathrm{P}(\mathrm{R}>3.0864)=\mathrm{F}(9,9,3.0864)=0.0543$. The two-tailed test result showed that there is a significant variation in both the pre pension investment funds (PPIF) and postpension investment funds (POPIF) in Nigeria.

The implication of the above result is that there is variation in the pension investment funds during pre- and post-pension era in Nigeria. The mean plot below showed a remarkable and significant variation in the pension investment funds during pre- and post-pension era in Nigeria.

Figure 1 shows that the post-pension era recorded the highest mean (24.793) compared to prepension era (21.894). 
Fig. 1: Mean Plot of Pre and Post Pension Investment Funds

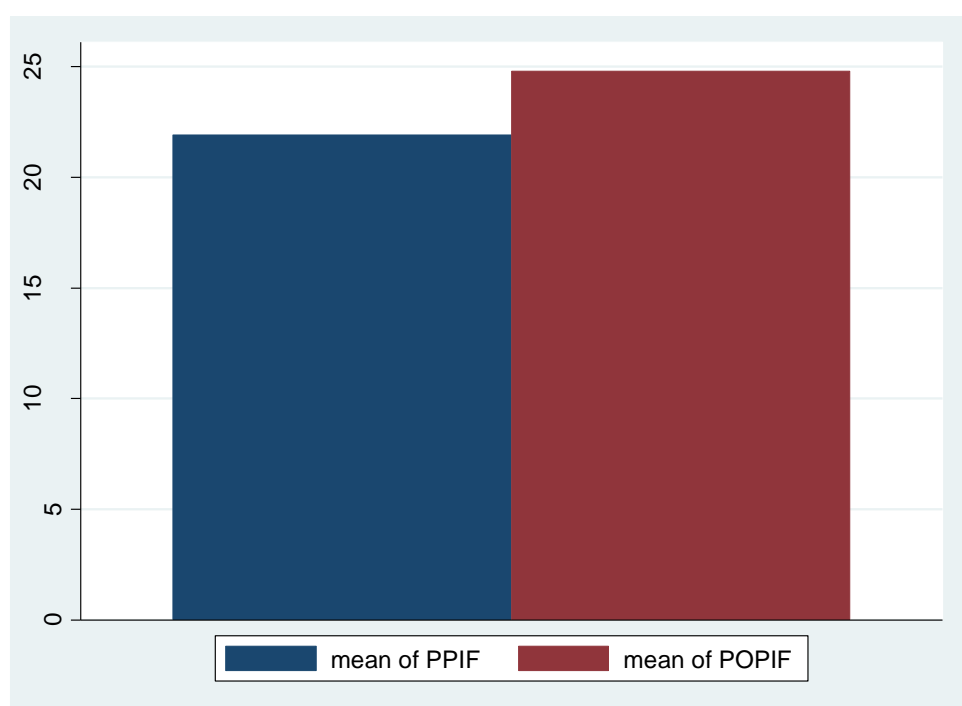

On the basis of this, we can infer that the new scheme (contributory scheme: post-pension era) is healthy and reliable. Thus, the contributory pension scheme (post-pension era) significantly improved as a result of the reform in Nigeria, especially in the area of pension investment funds.

\section{Conclusion and Recommendations}

Pension scheme is a way of taking care of the future of Nigerian workers when they retire from service but this has not been realized in the country in time past. However, this paper comparatively evaluated the contributory and non-contributory pension schemes in Nigeria so as to see the variation in both schemes as well as if the schemes have either improved or not. The results of our study revealed that the new scheme (contributory scheme) is healthy, reliable and poised towards helping retirees survive as soon as they retire from service. Thus, the contributory pension scheme significantly improved as a result of the reform in Nigeria. The improvement may be attributable to the fact that the contributory scheme places in the hands of the contributors and their employers, the obligation for the contribution that is available in the Retirement Savings Account (RSA) upon retirement as well as significant investments of pension funds.

On the basis of the findings, it was recommended that there should be an unrestricted RSA and non-remittance of pension contributions by employers to PENCOM. In terms of investments of pension fund, a better return on investment and service delivery from pension fund administrator should be enhanced so as to enhance voluntary contributions. Besides this, the internal procedures should be improved upon so that contributions and returns on pension investments due to retirees can be efficiently and swiftly made from pension fund administrators to pensioners on retirement. We proposed that the contributory pension scheme should be revitalized by a way of sensitizing organizations and employees on the need to uphold this new scheme. Also, PENCOM should from time to time, inspect operators in the area of prompt payment of retirement benefits to retirees. We believe that if the above suggestions are taken into consideration, pension reform objectives will be realized and appreciated by Nigerians. 


\section{References}

Ahmad, M.K. (2006). The contributory pension scheme: institutional and legal frameworks. CBN Bullion, 30(2), 1-18

Ahmed, I.K. Abayomi, O.A. \& Nureni, S.A. (2016). Effects of contributory pension scheme on employees' productivity: Evidence from Lagos State Government. African Journal of Business Management, 10(16), 384-396.

Ahmed, T.D. \& Oyadiran, P.A. (2013). An analysis of the impact of the 2004 pension policy on the welfare of the Nigerian civil servants: A case study of selected federal ministries. European Centre for Research Training and Development, 1(4), 20-55

Akalonu, R.O. \& Ipinyomi, R.A. (2014). Comparative analysis of the benefits of the Nigerian pension reform act No. 102 of 1979 and the pension reform act of 2004. International Journal of Scientific Research and Management, 2(3), 579-598

Anazodo, R.O., Ezenwile, U., Chidolue, D.N. \& Umetiti, C. (2014). The effect of new pension scheme on retirees in Nigeria: 2004-2014. Review of Public Administration Management, 3(6), 180-190

Ayegba, O. (2013). An evaluation of pension administration in Nigeria. British Journal of Arts and Social Sciences, 15(2), 97-108

Edogbanya, A. (2013). An assessment of the impact of contributory pension scheme to Nigerian economic development. Global Journal of Management and Business Research, 13(2), 47-59.

Essien, E.B. \& Akuma, M.S. (2014). The new contributory pension scheme in Nigeria: Gleaning from past pension scheme. IOSR Journal of Economics and Finance, 2(5), $33-40$

Ezegwu, C.I. \& Itodo, A.A. (2014). Portfolio analysis of pension fund investments in Nigeria. Kuwait Chapter of Arabian Journal of Business and Management Review, 3(12), 4158

Markowski, C.A. \& Markowski, E.P. (1990). Conditions for the effectiveness of a preliminary test of variance. American Statistician44:322-326.

Nwanne, T.F.I. (2015). Impact of contributory pension scheme on economic growth in Nigeria. Global Advanced Research Journal of Management and Business Studies, 4(8), 333337

Odia, J.O. \& Okoye, A.E. (2012). Pension reform in Nigeria: A comparison between the old and new scheme, Afro Asian Journal of Social Sciences, 3(1), 1-17.

Odo, C.O. Igbeka, V.C. \& Ani, W.U. (2011). Public sector pension reform in Nigeria: A historical perspective. JORIND, 9(2), 306-314

Osondu, M.O. (2016). Implementation of the 2004 pension reform act in federal tertiary institutions in the south-east states, Nigeria. Public Policy and Administration Research, 6(7), 76-88

Proshare Ecosystem (2016). Nigerian Stock Exchange pension index. Lagos: Proshare Investment Club, July 6, pp.1-5.

Stewart, F. \& Yermo, J. (2009). Pensions in Africa. OECD Working Papers on Insurance and Private Pensions, No. 30, OECD. 


\section{Appendix}

\section{Secondary Data Output via STATA 13.0 Version}

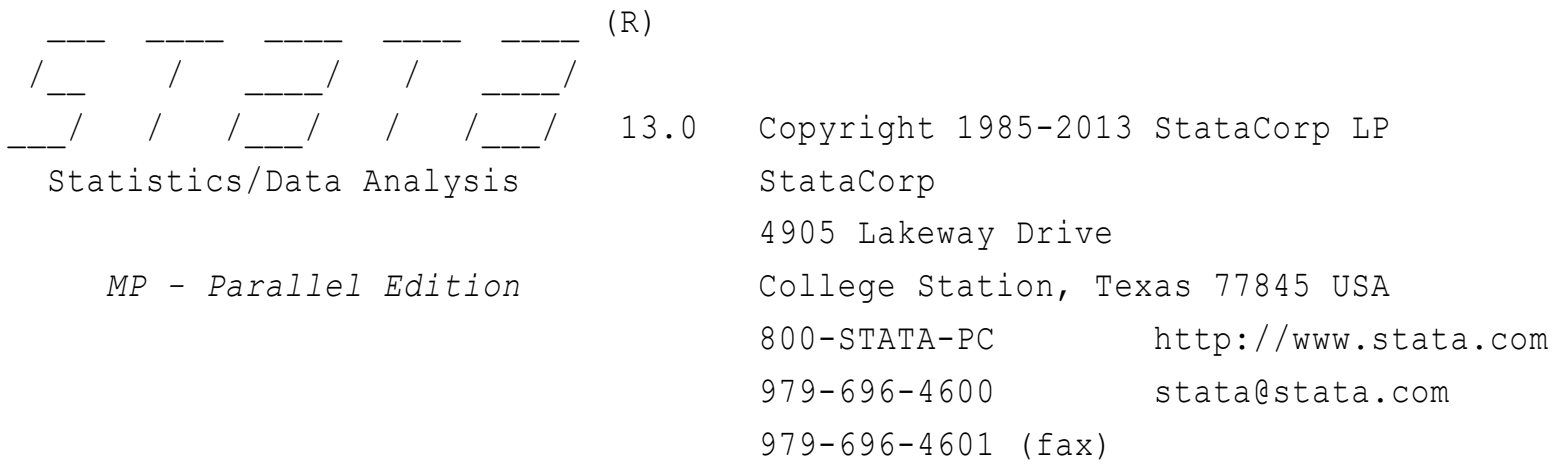

3-user 8-core Stata network perpetual license:

Serial number: 501306208483

Licensed to: ORACLE

ORACLE

Notes:

1. (/v\# option or - set maxvar-) 5000 maximum variables

- *(2 variables, 10 observations pasted into data editor)

- rename varl PPIF

- rename var2 POPIF

- sdtest $\mathrm{PPIF}==$ POPIF

Variance ratio test

\begin{tabular}{|c|c|c|c|c|c|c|}
\hline Variable & $\mathrm{Obs}$ & Mean & Std. Err. & Std. Dev. & [95\% Conf. & Interval] \\
\hline PPIF & 10 & 21.894 & 1.681156 & 5.316282 & 18.09096 & 25.69704 \\
\hline POPIF & 10 & 24.793 & .9569291 & 3.026076 & 22.62828 & 26.95772 \\
\hline combined & 20 & 23.3435 & .998421 & 4.465074 & 21.25378 & 25.43322 \\
\hline
\end{tabular}
$\mathrm{Ha}:$ ratio $<1$
Ha: ratio $!=1$
$\mathrm{Ha}:$ ratio $>1$
$\operatorname{Pr}(F<f)=0.9457$
$2 * \operatorname{Pr}(F>f)=0.1085$
$\operatorname{Pr}(F>f)=0.0543$ 